\title{
Peningkatan Hasil Pembelajaran Pendidikan Agama Buddha Materi Penghormatan Melalui Penggunaan Audio Visual Berbasis Kontekstual
}

\author{
Sidartha Adi Gautama, Dwi Yulianti, Taridi \\ Pendidikan Guru Sekolah Dasar, Universitas Lampung \\ Jln. Prof. Dr. Soemantri Brojonegoro No. 1 Bandar Lampung 45145 \\ E-mail: deviyanti.pangestu@fkip.unila.ac.id
}

\section{Article Info \\ Received April 2019 \\ Accepted Agustus 2019 \\ Published Oktober 2019}

Keywords:

audio-visual, contextual teaching material,

Buddhist education

\begin{abstract}
This study aims are to: 1) Describe the conditions and potential of learning using contextual-based audio-visual teaching materials. 2) Produce contextual based audio visual teaching material products. 3) Analyze effectiveness and attractiveness to improve student learning outcomes in the learning process after using contextually-based audio-visual teaching materials in learning Buddhist education. This study uses the research and development approach of Bord and Gall. The study was conducted at SD Tunas Mekar Indonesia Bandar Lampung. Observation instrument data collection techniques, then data were analyzed quantitatively and qualitatively. Based on observational research and the development of contextual-based audio-visual teaching materials it is very supportive and possible to do contextual learning based on 0.67 and product attractiveness has a success rate of $82 \%$. Audio visual teaching materials are able to increase the value of the material Anjali from 66.6 become 88. While in the material Namaskhara there is a change in the value before using the product that developed the average value of students 69.6 become 83, and in the Uttana material the average value of students also experienced significant changes from68.4 to 90. This value is a very meaningful value for improving student learning outcomes so that context-based audio-visual teaching material has been proven to improve learning outcomes in material ways of giving respect in Buddhism in class I SD Tunas Mekar Indonesia Bandar Lampung.
\end{abstract}

\begin{abstract}
Abstrak : Penelitian ini bertujuan untuk: 1) Mendeskripsikan kondisi dan potensi pembelajaran dengan menggunakan bahan ajar audio visual berbasis kontekstual. 2) Menghasilkan produk bahan ajar audio visual berbasis kontekstual. 3) Menganalisis efektivitas dan daya tarik untuk meningkatkan hasil belajar siswa dalam proses pembelajaran setelah menggunakan bahan ajar audio visual berbasis kontekstual dalam pembelajaran pendidikan agama Buddha. Penelitian ini menggunakan pendekatan penelitian dan pengembangan dari Bord and Gall. Penelitian dilakukan di SD Tunas Mekar Indonesia Bandar Lampung. Teknik pengumpulan data instrumen observasi, kemudian data dianalisis secara kuantitatif dan kualitatif. Berdasarkan penelitian observasional dan pengembangan bahan ajar audio visual berbasis kontekstual sangat mendukung dan memungkinkan dilakukan pembelajaran kontekstual berbasis 0.67 dan product attractiveness memiliki tingkat keberhasilan $82 \%$. Bahan ajar audio visual mampu meningkatkan nilai materi
\end{abstract}


Anjali dari 66,6 menjadi 88. Sedangkan pada materi Namaskhara terjadi perubahan nilai sebelum menggunakan produk sehingga nilai rata-rata siswa yang dikembangkan 69,6 menjadi 83, dan pada materi Uttana. materi nilai rata-rata siswa juga mengalami perubahan yang signifikan dari 68,4 menjadi 90. Nilai tersebut merupakan nilai yang sangat berarti untuk meningkatkan hasil belajar siswa sehingga bahan ajar audio visual berbasis konteks terbukti dapat meningkatkan hasil belajar pada materi cara memberi Menghormati Agama Buddha di kelas I SD Tunas Mekar Indonesia Bandar Lampung.

Kata kunci : audio-visual, materi pengajaran kontekstual, pendidikan Buddha.

(C2019 Jurusan Ilmu Pendidikan, FKIP Universitas Lampung p-ISSN (Media Cetak) 2656-8527

\section{PENDAHULUAN}

Pendidikan agama Buddha menjadi mata pelajaran wajib untuk pembelajaran agama Buddha Sekolah Dasar Tunas Mekar Indonesia Bandar Lampung. Oleh karena itu mata pelajaran pendidikan agama Buddha di sekolah harus dikelola dengan baik dan harus mendapat perhatian yang lebih agar dapat memberikan bekal yang kuat bagi siswa sebagai landasan moral dan etika peserta didik. Pendidikan agama harus diperkuat dalam hal ini pembelajaran di Sekolah Dasar (SD) yang akan menjadi pondasi yang kuat bagi siswa pada jenjang berikutnya. Pendidikan agama di SD akan berhasil dengan baik apabila guru memahami perkembangan intelektual anak usia SD. Mata pelajaran agama di SD bertujuan agar siswa mampu mengembangkan pengetahuan, keterampilan dan pemahaman yang bermanfaat dan dapat diterapkan dalam kehidupan sehari-hari.

Daryanto (2013) yang mengungkapkan bahwa belajar dapat diartikan sebagai proses perubahan prilaku sebagai akibat interaksi individu dengan lingkungan. Perubahan prilaku tersebut mencakup pengetahuan, pemahaman, ketrampilan, sikap dan sebagainya yang dapat maupun tidak dapat diamati. Salah satu teori yang terkenal berkaitan dengan teori belajar konstruktivisme adalah perkembangan mental Piaget. Teori ini biasa di sebut teori berkembangan intelektual atau perkembangan kognitif. Teori tersebut berkenaan dengan kesiapan anak untuk belajar yang dikemas dalam tahap perkembangan intelektual dari lahir hingga dewasa. Setiap tahap perkembangan intelektual yang dimaksud dilengkapi dengan ciri-ciri tertentu 
dalam mengkonstruksi ilmu pengetahuan. Sebagai contoh pada tahap sensori motor anak berfikir melalui gerakan atau perbuatan Ruseffendi dalam Pranita (2010). Menurut Herpratiwi (2009) mengidentifikasikan bahwa teori belajar konstruktivis bahwa peristiwa pembelajaran pada dasarnya tidak lagi seperti konsep terdahulu seorang pendidik mentransfer pengetahuan kepada peserta didik menemukan sebuah permasalahan dan tujuan setiap materi pembelajaran. Artinya pengetahuan juga bukan merupakan sesuatu yang sudah ada melainkan suatu proses yang berkembang terus menerus. Dalam proses ini keaktifan seseorang sangat menentukan dalam mengembangkan pengetahuanya.

Prastowo (2012) bahan ajar pada dasarnya merupakan segala bahan (baik informasi, alat, maupun teks) yang disusun secara sistematis, yang menampilkan sosok utuh dari kompetensi yang akan dikuasai peserta didik dan digunakan dalam proses pembelajaran dengan tujuan perencanaan dan penelaahan implementasi pembelajaran. Berdasarkan beberapa pendapat para ahli di atas peneliti menyimpulkan bahwa ketercapaian kompetensi pembelajaran ditentukan dengan adanya bahan ajar yang berisi seperangkat materi pembelajaran, metode dengan menggunakan teknologi yang didesain secara sistematis dan menarik sehingga memberi dampak pengetahuan, keterampilan dan perubahan sikap kepada peserta didik. Menurut Sagala (2008) kontekstual merupakan konsep belajar yang membantu guru mengaitkan antara materi yang diajarkan dengan situasi dunia nyata dan mendorong peserta didik membuat hubungan antara pengetahuan yang dimiliki dengan penerapannya dalam kehidupan mereka sebagai anggota masyarakat. Pembelajaran kontekstual adalah pendekatan pembelajaran yang mengkaitkan antara materi yang dipelajari dengan kehidupan nyata peserta didik itu sehari-hari, baik dalam lingkungan keluarga, sekolah, masyarakat maupun warga negara dengan tujuan untuk menemukan makna materi tersebut bagi kehidupannya (Komalasari, 2015).

Menurut Mukti (2006) pendidikan agama Buddha bertujuan agar peserta didik memiliki kemampuan sebagai berikut; (1) mengembangkan keyakinan (Saddha) dan ketakwaan (Bhakti) kepada Tuhan Yang Maha Esa, Tiratana, para Bodhisattva dan Mahasattva, (2) mengembangkan manusia Indonesia yang berakhlak mulia 
melalui peningkatan pelaksanaan moral (Sila), meditasi (Samadhi) dan kebijaksanaan (Panna) sesuai dengan Buddha Dharma (Agama Buddha), (3) mengembangkan manusia Indonesia yang memahami, menghayati, dan mengamalkan/menerapkan Dharma sesuai dengan Ajaran Buddha yang terkandung dalam Kitab Suci Tipitaka/Tripitaka sehingga menjadi manusia yang bertanggung jawab sesuai dengan prinsip Dharma dalam kehidupan sehari-hari, (4) memahami agama Buddha dan sejarah perkembangannya di Indonesia. Ruang lingkup Pendidikan Agama Buddha meliputi aspek-aspek sebagai berikut; (1) sejarah, (1) keyakinan (Saddha), (3) perilaku/moral (Sila), (4) Kitab Suci Agama Buddha Tripitaka (Tipitaka), (5) meditasi (Samadhi), (6) kebijaksanaan (Panna).

Menurut Heinich (2010) rencana pembelajaran merupakan persiapan mengajar yang berisi hal- hal yang perlu atau harus dilakukan oleh guru dan siswa dalam melaksanakan kegiatan pembelajaran yang antara lain meliputi; pemilihan materi, metode, media, dan alat evaluasi. Rencana pembelajaran merupakan realisasi dri pengalaman belajar peserta didik yang diterapkan dalm silabus. Rencana pembelajaran merupakan rencana atau program yang disusun guru untuk satu kali pertemuan atau lebih, untuk mencapai target satu kompetensi dasar sehingga indikotor pencapaian kompetensi tercapai.

Perencanaan pembelajaran memiliki manfaat diantaranya; guru akan terhindar dari keberasilan secara tidak sengaja, karena perencanaan disusun untuk mencapai hasil yang maksimal, dapat menentukan langkah dan strategi yang tepat dalam pembelajaran; dapat menentukan langkah dan strategi yang tepat dalam pembelajaran; dapat menentukan dan mempersiapkan berbagai alat dan fasilitas yang diperlukan dalam pembelajaran.

Tujuan penelitian: 1) Mendiskripsikan kondisi dan potensi pembelajaran menggunakan bahan ajar audio visual berbasis kontekstual. 2) Menghasilkan produk bahan ajar audio visual berbasis kontekstual pada mata pelajaran pendidikan agama Buddha. 3) Menganalisis efektifitas dan kemenarikan untuk meningkatkan hasil belajar peserta didik pada proses pembelajaran setelah menggunakan bahan ajar audio visual berbasis kontekstual pada mata pelajaran pendidikan agama Buddha kelas 1 di Sekolah Dasar Tunas Mekar Indonesia Bandar Lampung. 


\section{METODE}

Penelitian ini menggunakan desain Research and development ( $R$ \& D) artinya penelitian dan pengembangan suatu produk baru atau menyempurnakan produk yang telah ada yang dapat dipertangung jawabkan. Penelitian ini amengikuti langkah penelitian dan pengembangan dari Borg and Gall, prosedur penelitian pengembangan berdasarkan langkah-langkah penelitian dan pengembangan ini mengacu pada R\&D (Sugiono. 2015).

Penelitian dilaksanakan di SD Tunas Mekar Indonesia Bandar Lampung. Penelitian ini dilaksanakan pada semester ganjil tahun pelajarn 2018-2019. Kompetensi dasar dalam penelitian ini adalah Menyajikan cara-cara menghormat, salam dan simbol-simbol agama Buddha. Data dikumpulkan dengan instrument pengamatan serta dianalisis dengan presentasi deskripsi.

\section{HASIL DAN PEMBAHASAN}

Berdasarkan hasil penelitian dan pengembangan $(R \& D)$ ini menggunakan kelas eksperimen tanpa menggunakan kelas kontrol. Pengolahan data pada penelitian ini menggunakan pendekatan kuantitaf dan kualitatif, data yang diperoleh berupa penilaian peserta didik sebelum diberi perlakuan (Pretest) dan nilai peserta didik setelah diberi perlakuan (Posttest). Kemudian data diolah dengan menggunakan uji $\mathrm{N}$-gain untuk melihat efektivitas penggunaan produk sementara pendekatan kualitatif menggunakan instrumen guna melihat seberapa besar pengaruh daya tarik pada penggunakaan produk yang dikembangkan tersebut.

Potensi dan masalah pada penelitian pengembangan ini didasarkan atas hasil analisis kebutuhan yang dilakukan oleh peneliti dengan tujuan untuk mengidentifikasi masalah. Berdasarkan hasil observasi, 40\% siswa SD Tunas Mekar Indonesia Bandar Lampung tidak bisa mempraktekkan sikap namaskhara yang benar. $60 \%$ siswa bisa mempraktekkan sikap anjali, 60\% siswa bisa mempraktekkan sikap uttana, atau terdapat masalah pada KD (Kompetensi Dasar) 4.1. menyajikan cara-cara menghormat, salam dan simbol-simbol agama Buddha berdasarkan IPK (Indikator Pencapaian Kompetensi) 4.1.1 Mendemonstrasikan cara menghormat dengan Anjali, Namaskkhara, dan Uttana. Dapat diskipsikan bahwa rata-rata hanya 
$60 \%$ peserta didik dikelas 1 yang memiliki nilai di atas KKM dengan nilai KKM $\geq$ 75 dan rata-rata di kelas 1 memiliki dibawah $\mathrm{KKM}$ dengan nilai $\mathrm{KKM} \geq 75$, hal ini seperti terlihat pada tabel 1.1

Tabel 1. Persentase KKM

\begin{tabular}{llll}
\hline Nilai & Materi & Presentase & Keterangan \\
\hline$\geq 75$ & Anjali & $40 \%$ & Diatas KKM \\
$<75$ & & $60 \%$ & Dibawah KKM \\
$\geq 75$ & Namaskhara & $20 \%$ & Diatas KKM \\
$<75$ & & $80 \%$ & Dibawah KKM \\
$\geq 75$ & & $40 \%$ & Diatas KKM \\
$<75$ & Uttana & $60 \%$ & Dibawah KKM \\
\hline
\end{tabular}

Seluruh rangkaian validasi produk audio visual berbasis kontekstual pendidikan Agama Buddha mengalami kenaikan jika dilihat dari rata-rata validasi ahli media, validasi ahli desain dan validasi ahli materi dari penilaian pertama dengan dan penilaian tahap kedua adanya progres yang baik setelah dilakukan penilaian dan revisi sehingga dapat disimpulkan bahwa produk bahan ajar audio visual berbasis kontekstual pendidikan agama Buddha layak dilakukan ujicoba ke tahap selanjutnya.

Tabel 1.2 Presentase Penilaian uji Validasi ahli pada tahap I dan II

\begin{tabular}{lllll} 
No & Validasi & $\begin{array}{l}\text { Penilaian } \\
\text { I }(\%)\end{array}$ & $\begin{array}{l}\text { Penilaian } \\
\text { II }(\%)\end{array}$ & Keterangan \\
\hline 1 & Media & 95,3 & 98,4 & Meningkat \\
2 & Desain & 92,3 & 98,1 & Meningkat \\
3 & Materi & 95 & 100 & Meningkat
\end{tabular}

Berdasarkan validasi ahli media, ahli desain, dan ahli materi tahap I dan II pada tabel 4.5 di atas dapat diketahui bahwa jumlah skor yang diperoleh validasi media pada penilaian I sebesar 95,3\% dan terjadi peningkatan pada penilaian ke II sebesar 
98, $4 \%$. Skor yang diperoleh validasi desain pada penilaian I sebesar 92,3\% dan terjadi peningkatan pada penilaian ke II sebesar 98, $1 \%$. Skor yang diperoleh ahli materi pada penilaian I sebesar $95 \%$ dan terjadi peningkatan pada penilaian ke II sebesar $100 \%$.

Setelah melalui proses validasi ahli media, ahli desain, dan ahli materi serta mendapatkan data hasil kualitas bahan ajar audio visual berbasis kontekstual pendidikan agama Buddha yang dikembangkan proses selanjutnya adalah melakukan ujicoba penggunaan oleh peserta didik di SD Tunas Mekar Indonsia Bandar Lampung. Ujicoba pemakaian ini dibagi tiga yaitu uji terbatas pada uji satu-satu, ujicoba kelompok kecil, dan ujicoba lapangan aatau kelompok besar. Sampel uji satu-satu adalah 2 peserta didik, data dari uji coba satu-satu dan kelompok kecil adalah hasil belajar peserta didik menggunakan bahan ajar audio visual berbasis kontekstual data diambil berdasrkan hasil nilai prestest dan posttest berikut nilai-nilai rata-rata dari masing-masing ujicoba;

Tabel 1.3 Nilai pretest dan posttest uji coba satu-satu dan kelompok kecil (Anjali)

\begin{tabular}{lllll}
\hline Data & Hasil & Uji & Satu-satu & Hasil Uji Kelompok kecil \\
Statistik & Anjali & & Anjali & \\
& Pre-Test & Post-Test & Pre-Test & Post-Test \\
\hline Rata-rata & 79 & 96 & 58,3 & 83 \\
Minimal & 75 & 92 & 50 & 75 \\
Maksimal & 83 & 100 & 67 & 92 \\
\hline
\end{tabular}

Berdasarkan tabel data 4,6 nilai pretest pada ujicoba satu-satu nilai terkecil 75 dan nilai terbesar 83 memiliki nilai rata-rata sebesar 79. Pada nilai posttest ujicoba satu-satu nilai terkecil 92 dan nilai terbesar 100 dengan nilai rata-rata 96 berarti terjadi pergeseran peserta didik yang sebelumnya nilai terendah 75 dan terbesar 83 bermigrasi ke nilai terkecil 92 dan terbesar 100 dengan rata-rata 96. Sehingga dapat disimpulkan bahwa nilai pretest uji coba satu-satu mengalami kenaikan yang signifikan pada aat peserta didik melaksanakan posttest. Begitu pula pada hasil nilai ujicoba kelompok kecil nilai terkecil 50 dan nilai tertinggi 67 dengan nilai rata-rata 58,3 , setelah melaksanakan posttest ujicoba kelompok kecil maka nilai minimum 
sebelumnya 75 menjadi 92 rata-rata 83 disini terlihat peserta didik yang memiliki nilai minimum 50 bergeser ke nilai minimum 75 dan maksimum 92. Dari ujicoba ini dapat disimpulkan bahwa nilai pretest ke posttes pada ujicoba satu-satu dan ujicoba kelompok kecil peserta didik turun atau menyempit sehingga peserta didik yang memiliki kemampuan kurang dalam belajar setelah diberikan perlakuan bahan ajar audio visual berbasis kontekstual menjadi naik kemampuannya sementara peserta didik yang memiliki kemampuan sedang dan tinggi tetap memiliki hasil belajar yang tinggi.

\section{Tabel 2. Nilai pretest dan posttest uji coba satu-satu dan kelompok kecil (Namaskhara)}

\begin{tabular}{|c|c|c|c|c|}
\hline \multirow{2}{*}{$\begin{array}{l}\text { Data } \\
\text { Statistik }\end{array}$} & \multicolumn{2}{|c|}{$\begin{array}{l}\text { Hasil Uji Satu-satu } \\
\text { Namaskhara }\end{array}$} & \multicolumn{2}{|c|}{$\begin{array}{l}\text { Hasil Uji Kelompok kecil } \\
\text { Namaskhara }\end{array}$} \\
\hline & Pre-Test & Post-Test & Pre-Test & Post-Test \\
\hline Rata-rata & 77 & 92 & 65 & 78 \\
\hline Minimal & 70 & 88 & 58 & 75 \\
\hline Maksimal & 83 & 96 & 70 & 83 \\
\hline
\end{tabular}

Berdasarkan tabel data 4,7 nilai pretest pada ujicoba satu-satu nilai terkecil 70 dan nilai terbesar 83 memiliki nilai rata-rata sebesar 77. Pada nilai posttest ujicoba satu-satu nilai terkecil 88 dan nilai terbesar 96 dengan nilai rata-rata 92 berarti terjadi pergeseran peserta didik yang sebelumnya nilai terendah 70 dan terbesar 83 bermigrasi ke nilai terkecil 88 dan terbesar 96 dengan rata-rata 92. Sehingga dapat disimpulkan bahwa nilai pretest uji coba satu-satu (Namaskhara) mengalami kenaikan yang signifikan pada aat peserta didik melaksanakan posttest. Begitu pula pada hasil nilai ujicoba kelompok kecil nilai terkecil 58 dan nilai tertinggi 70 dengan nilai rata-rata 65 , setelah melaksanakan posttest ujicoba kelompok kecil maka nilai minimum sebelumnya 75 menjadi 83 rata-rata 78 disini terlihat peserta didik yang memiliki nilai minimum 58 bergeser ke nilai minimum 75 dan maksimum 70 menjadi 83. Dari ujicoba ini dapat disimpulkan bahwa nilai pretest ke posttes pada ujicoba satu-satu dan ujicoba kelompok kecil peserta didik turun atau menyempit sehingga peserta didik yang memiliki kemampuan kurang dalam belajar setelah diberikan perlakuan bahan ajar audio visual berbasis kontekstual menjadi naik 
kemampuannya sementara peserta didik yang memiliki kemampuan sedang dan tinggi tetap memiliki hasil belajar yang tinggi.

Tabel 3. Nilai pretest dan posttest uji coba satu-satu dan kelompok kecil (Uttana)

\begin{tabular}{lllll}
\hline $\begin{array}{l}\text { Data } \\
\text { Statistik }\end{array}$ & $\begin{array}{l}\text { Hasil Uji } \\
\text { Uttana } \\
\text { Pre-Test }\end{array}$ & Post-Test & $\begin{array}{l}\text { Satu-satu } \\
\text { Pttana } \\
\text { Pre-Test }\end{array}$ & Post-Test \\
\hline Rata-rata & 79 & 96 & 61 & 86 \\
Minimal & 75 & 92 & 50 & 83 \\
Maksimal & 83 & 100 & 67 & 92 \\
\hline
\end{tabular}

Berdasarkan tabel data 4,8 nilai pretest pada ujicoba satu-satu nilai terkecil 75 dan nilai terbesar 83 memiliki nilai rata-rata sebesar 79. Pada nilai posttest ujicoba satu-satu nilai terkecil 92 dan nilai terbesar 100 dengan nilai rata-rata 96 berarti terjadi pergeseran peserta didik yang sebelumnya nilai terendah 75 dan terbesar 92 bermigrasi ke nilai terkecil 92 dan terbesar 100 dengan rata-rata 96. Sehingga dapat disimpulkan bahwa nilai pretest uji coba satu-satu mengalami kenaikan yang signifikan pada aat peserta didik melaksanakan posttest. Dari ujicoba ini dapat disimpulkan bahwa nilai pretest ke posttes pada ujicoba satu-satu dan ujicoba kelompok kecil peserta didik turun atau menyempit sehingga peserta didik yang memiliki kemampuan kurang dalam belajar setelah diberikan perlakuan bahan ajar audio visual berbasis kontekstual menjadi naik kemampuannya sementara peserta didik yang memiliki kemampuan sedang dan tinggi tetap memiliki hasil belajar yang tinggi. 

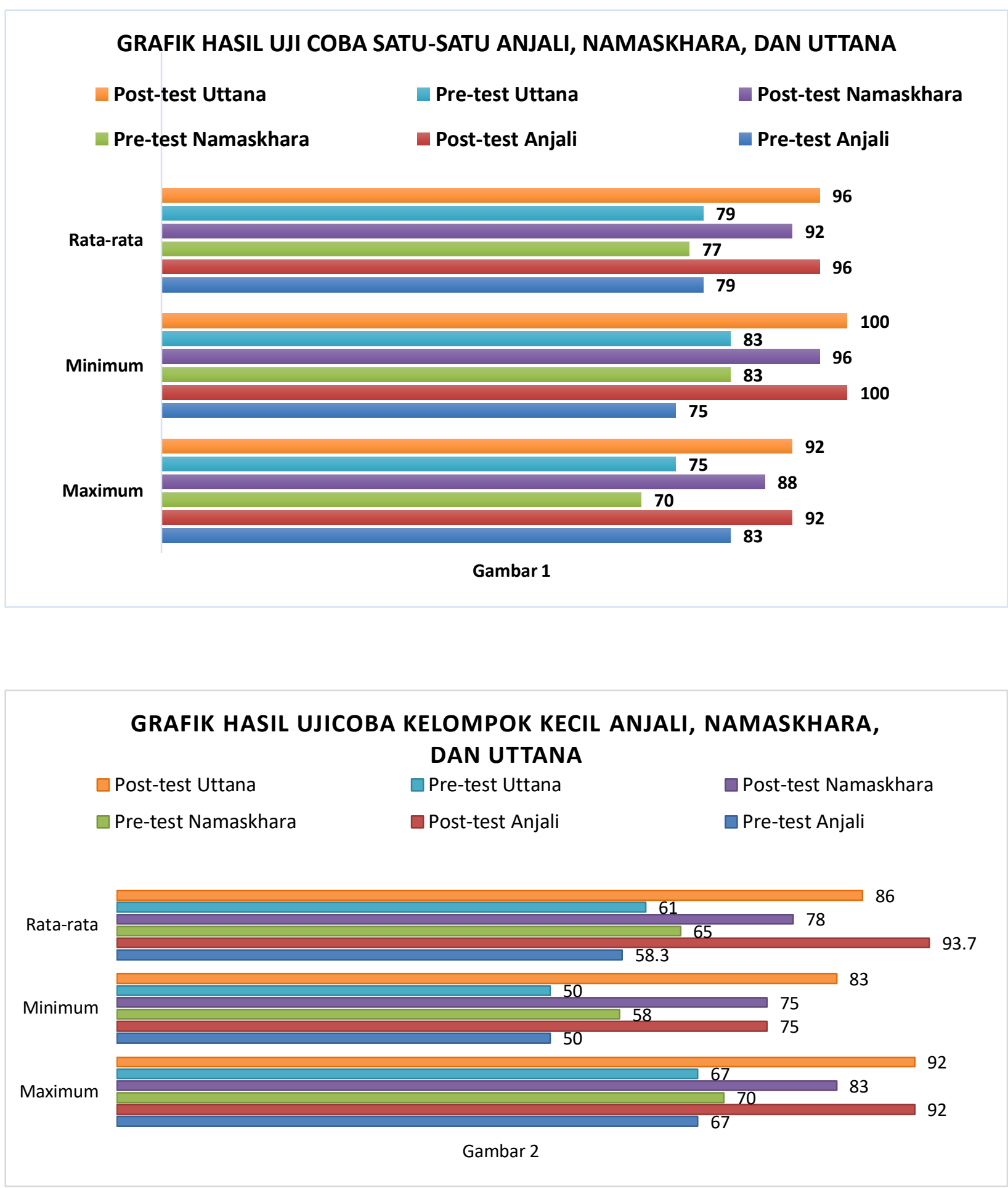

Secara umum dapat dilihat bahwa nilai rata-rata dari ujicoba satu-satu praktek Anjali pada nilai pretest memiliki rata-rata 68 dan nilai posttest 89 sehingga terdapat selisih 21 atau mengalami kenaikan sebesar $21 \%$, ujicoba satu-satu praktek Namaskhara pada nilai pretest memiliki rata-rata 77 dan nilai posttest 92 sehingga 
terdapat selisih 15 atau mengalami kenaikan sebesar $15 \%$, ujicoba satu-satu praktek Uttana pada nilai pretest memiliki rata-rata 79 dan nilai posttest 96 sehingga terdapat selisih 20 atau mengalami kenaikan sebesar $20 \%$.

Nilai rata-rata dari ujicoba kelompok kecil praktek Anjali pada nilai pretest memiliki rata-rata 58, 3 dan nilai posttest 83 sehingga terdapat selisih 24,7 atau mengalami kenaikan sebesar $25 \%$, ujicoba kelompok kecil praktek Namaskhara pada nilai pretest memiliki rata-rata 65 dan nilai posttest 78 sehingga terdapat selisih 13 atau mengalami kenaikan sebesar $13 \%$, ujicoba kelompok kecil praktek Uttana pada nilai pretest memiliki rata-rata 61 dan nilai posttest 86 sehingga terdapat selisih 25 atau mengalami kenaikan sebesar $25 \%$.

Nilai rata-rata dari ujicoba kelompok besar praktek Anjali pada nilai pretest memiliki rata-rata 66, 6 dan nilai posttest 88 sehingga terdapat selisih 21, 4 atau mengalami kenaikan sebesar 21, $4 \%$, ujicoba kelompok besar praktek Namaskhara pada nilai pretest memiliki rata-rata 68 dan nilai posttest 83 sehingga terdapat selisih 15 atau mengalami kenaikan sebesar $15 \%$, ujicoba kelompok besar praktek Uttana pada nilai pretest memiliki rata-rata 68,4 dan nilai posttest 90 sehingga terdapat selisih 21, 6 atau mengalami kenaikan sebesar $22 \%$, sehingga dapat disimpulan secara keseluruhan bahwa terdapat peningkatan hasil rata-rata posttest terhadap nilai pretest hal ini memiliki dampak baik bagi peningkatan hasil belajar peserta didik di SD Tunas Mekar Indonesia Bandar Lampung setelah pembelajaran menggunakan bahan ajar audio visual berbasis kontekstual pendidikan Agama Buddha. Selain itu terlihat bahwa peserta didik yang memiliki kemampuan rendah dan sedang menjadi tinggi dan peserta didik dengan kemampuan tinggi tetap mengdapatkan hasil yang tinggi ketika pembelajaran menggunakan bahan ajar audio visual berbasis kontekstual. Menurut peserta didik kegiatan pembelajaran menggunakan bahan ajar audio visual berbasis kontekstual dapat memberikan motivasi peserta didik untuk belajar dan mempermudah untuk mempraktekkan cara-cara menghormat serta mudah dimengerti. Kombinasi buku paket dan bahan ajar audio visual lebih memiliki daya tarik bagi peserta didik, peserta didik lebih semangat belajar karena video tersebut sangat membantu peserta didik untuk mempraktekkan cara-cara menghormat. 
Tabel 4 Nilai Rata-rata pretest dan posttest pada ujicoba I dan II

\begin{tabular}{lcccccc}
\hline & \multicolumn{7}{c}{ Hasil Uji Kelompok Besar } \\
Ujicoba tahap I dan II & $\begin{array}{l}\text { Pre- } \\
\text { Test }\end{array}$ & $\begin{array}{l}\text { Post- } \\
\text { Test }\end{array}$ & $\begin{array}{l}\text { Pre- } \\
\text { Test }\end{array}$ & Post-Test & $\begin{array}{c}\text { Pre- } \\
\text { Test }\end{array}$ & $\begin{array}{c}\text { Post- } \\
\text { Test }\end{array}$ \\
\hline Ujicoba satu-satu & 79 & 96 & 77 & 92 & 79 & 96 \\
Ujicoba Kelompok kecil & 58,3 & 83 & 65 & 78 & 61 & 86 \\
Ujicoba kelompok besar & 66,6 & 88 & 68 & 83 & 68,4 & 90 \\
Rata-rata & 68 & 89 & 70 & 84,3 & 69,5 & 91 \\
Presentase & $68 \%$ & $89 \%$ & $70 \%$ & $84 \%$ & $70 \%$ & $91 \%$ \\
\hline
\end{tabular}

Uji efektivitas produk dilakukan dengan mengunakan $\mathrm{N}$-Gain ternormalisasi yaitu membendingkan hasil belajar peserta didik sebelum dan sesudah menggunakan bahan ajar audio visual berbasis kontekstual. Pembelajaran dikatakan efektif jika ( $N$ Gain) $\geq 0,70$. N-Gain diperoleh dari nilai pretest dan posttest.

Efektifitas diperoleh dengan menganalisis data kuantitatif dari nilai PretestPosttest. Nilai Pretest-Posttest kemudian diuji menggunakan rumus statistik dari data nilai pretest-posttest yang diperoleh juga dapat dilihat peningkatan hasil belajar ( $N$ Gain). Menurut Hake (dalam Niarti, 2017), besarnya peningkatan dihitung dengan rumus gain ternormalisasi (normalized gain) yaitu:

$$
g=\frac{\left(S_{f}\right)-\left(S_{i}\right)}{S_{m}-S_{i}}
$$

\section{Keterangan:}

g : gain ternormalisasi 


$$
\begin{array}{ll}
\left(\mathrm{S}_{\mathrm{f}}\right) & \text { : nilai posttest } \\
\left(\mathrm{S}_{\mathrm{i}}\right) & \text { : nilai pretest } \\
\mathrm{S}_{\mathrm{m}} & : \text { nilai maksimum }
\end{array}
$$

\begin{tabular}{|c|c|c|c|c|c|}
\hline \multirow{2}{*}{ Sampel } & \multicolumn{3}{|c|}{ N-Gain } & \multirow{2}{*}{ Klasifikasi } & \multirow{2}{*}{$\begin{array}{l}\text { Tingkat } \\
\text { efektifitas }\end{array}$} \\
\hline & ANJALI & NAMASKHARA & UTTANA & & \\
\hline $\begin{array}{l}\text { Ujicoba satu- } \\
\text { satu }\end{array}$ & 0,84 & 0,67 & 0,84 & Tinggi & Efektif \\
\hline Ujicoba & & & & & \\
\hline $\begin{array}{l}\text { Kelompok } \\
\text { kecil }\end{array}$ & 0,61 & 0,45 & 0,63 & Sedang & Tinggi \\
\hline Ujicoba & & & & & \\
\hline $\begin{array}{l}\text { kelompok } \\
\text { besar }\end{array}$ & 0,74 & 0,54 & 0,72 & Tinggi & Efektif \\
\hline Rata-rata & 0,73 & 0,56 & 0,73 & Tinggi & Efektif \\
\hline
\end{tabular}

Tabel 5. Nilai Uji efektifitas penggunan bahan ajar audio visual berbasis kontekstual

Berdasarkan tabel di atas diketahui bahwa $N$-Gain pada ujicoba satu-satu Anjali efektif karena 0,84 $\geq 0,70$. N-Gain pada ujicoba satu-satu Namaskhara efektif karena 0,67 $\leq$ 0,70. N-Gain pada ujicoba satu-satu Uttana efektif karena 0,84 $\geq 0,70$.

$N$-Gain pada ujicoba kelompok kecil Namaskhara efektif karena 0,67 $\leq 0,70$. $N$-Gain pada ujicoba kelompok kecil Uttana efektif karena 0,84 $\geq 0,70$.

$N$-Gain pada ujicoba kelompok besar Anjali efektif karena 0,74 $\geq 0,70 . N$ Gain pada ujicoba kelompok besar Namaskhara efektif karena 0,56 $\leq$ 0,70. N-Gain pada ujicoba kelompok besar Uttana efektif karena $0,73 \geq 0,70$. Dengan demikian dapat disimpulkan berdasarkan hasil perhitungan rata-rata $\mathrm{N}$-Gain ternormalisasi 0,73 dengan klasifikasi tinggi sehingga bahan ajar audio visual berbasis kontekstual pendidikan agama Buddha dapat digunakan pada peserta didik Sekolah Dasar Tunas Mekar Indonesia kelas 1 terbukti efektif. 
Kemenarikan pengguna bahan ajar audio visual berbasis kontekstual pendidikan agama Buddha di SD Tunas Mekar Indonesia Bandar Lampung dengan pengisian instrumen dengan cara membacakan instrumen tesebut kemudian peserta didik mengceklis nomor yang mereka inginkan, data yang diambil dari peserta didik kelas I

Tabel 6. Ujicoba kemenarikan pengguna bahan ajar audio visual berbasis kontekstual

\begin{tabular}{llll}
\hline No & Sampel & Prosentase & $\begin{array}{l}\text { Klasifikasi } \\
\text { Kemenarikan }\end{array}$ \\
\hline 1 & Ujicoba satu-satu & $80 \%$ & Menarik \\
2 & Ujicoba Kelompok kecil & $84 \%$ & Menarik \\
3 & Ujicoba Kelompok besar & $82 \%$ & Menarik \\
& Rata-rata & $82 \%$ & Menarik \\
\hline
\end{tabular}

Berdasarkan tabel 6 di atas disimpulakan bahwa penggunaan bahan ajar audio visual berbasis kontekstual pendidikan agama Buddha di kelas 1 SD Tunas Mekar Indonesia Bandar Lampung terbukti memiliki kemenarikan karena memperoleh prosentase rata-rata $82 \%$ dengan klasifikasi menarik.

\section{KESIMPULAN}

Simpulan berdasarkan hasil penelitian dan pembahasan adalah;

1. Berdasarkan hasil observasi yang dilakukan peneliti, peserta didik memiliki permasalahan pada saat melaksanakan proses pembelajaran yakni minimnya referensi bahan ajar yang mengandung unsur efektif dan menarik kenyataan ini membuat peserta didik kurang tertarik untuk terus belajar, sehingga hasil belajar pada Kompetensi Dasar (KD) 4.1 dibawah KKM.

2. Hasil penilaian validasi media pada validasi ke-II mengalami kenaikan sebesar 3,1 $\%$ dan dinyatakan sangan valid. Pada penilaian validasi desain pada validasi ke-II mengalami kenaikan sebesar 5,8 \% dan dinyatakan sangan valid. penilaian validasi materi pada validasi ke-II mengalami kenaikan sebesar $5 \%$ dan dinyatakan sangan valid dan siap diujicobakan. 
3. Penggunaan bahan ajar audio visual berbasis kontekstual pada mata pelajaran pendidikan agama Buddha kelas 1 Sekolah Dasar Tunas Mekar Indonesia Bandar Lampung terbukti efektif dengan kualifikasi tinggi, berdasarkan hasil perhitungan rata-rata $N$-Gain praktek Anjali $0,73 \geq 0,70$, berdasarkan hasil perhitungan ratarata $N$-Gain praktek Namaskhara $0,56 \geq 0,70$, berdasarkan hasil perhitungan ratarata $N$-Gain praktek Uttana $0,73 \geq 0,70$ dan jika dilihat dari nilai rata-rata pada ujicoba tahap I dan II nilai posttest praktek Anjali mengalami kenaikan terhadap nilai pretest yakni $21,4 \%$ dari nilai rata-rata pretest 66,6 dan nilai posttest 88 . Praktek Namaskhara mengalami kenaikan terhadap nilai pretest yakni $15 \%$ dari nilai rata-rata pretest 68 dan nilai posttest 83. Praktek Uttana mengalami kenaikan terhadap nilai pretest yakni $21,6 \%$ dari nilai rata-rata pretest 68,4 dan nilai posttest 90 .

4. Pada kemenarikan produk didapat data daya tarik diperoleh presentase rata-rata dari ujicoba sebesar $82 \%$ dengan klasifikasi menarik.

Saran berdasarkan hasil penelitian dan pembahasan adalah;

1. Bagi sekolah, sekolah memberikan dukungan dan fasilitas bagi pendidik lainnya untuk ikut mengembangkan bahan ajar audio visual berbasis kontekstual pada mata pelajaran lain yang diampu sehingga menumbuhkan kreatifitas bagi pendidik.

2. Bagi pendidik di SD, dapat menggunakan bahan ajar audio visual berbasis konekstual dalam proses pembelajaran pada KD 4.1 yang efektif dan menarik sehingga mendapatkan hasil belajar peserta didik yang optimal.

3. Bagi peserta didik, cara belajar peserta didik menjadi lebih baik dan maksimal dengan menggunakan bahan ajar audio visual berbasis kontekstual mata pelajaran pendidikan agama Buddha sebagai bahan ajar yang efektif dan mampu memberikan daya tarik.

4. Bagi peneliti lainnya dapat membuat bahan ajar audio visual berbasis kontekstual dengan menggunakan video animasi supaya hasil bahan ajar hasilnya lebih menarik dan lebih baik. 


\section{DAFTAR PUSTAKA}

Daryanto. (2013). Belajar dan Mengajar. Bandung. CV. Yrama Widya

Heinich, Alzen. (2010). The Practice of English Language Teaching (1st Edition). New York : Longman Inc

Herpratiwi. (2009). Teori Belajar dan Pembelajaran. Universitas Lampung: Lampung

Komalasari, kokom. (2015). Model pembelajaran kontekstual. Bandung: Refika aditama

Mukti, Krisnanda Wijaya. (2006), Wacana Buddha Dhamma. Jakarta: Yayasan Dhammadipa Arama

Niarti, N. (2017). Tesis. Pengembangan Bahan Ajar Berbasis Multimedia Interaktif Pada Materi Menyimak Untuk Peserta didik Kelas VI Sekolah Dasar, Universitas Lampung. Bandar Lampung (dipublikasikan).

Pranita,T. (2010). Teori Belajar Konstruktivisme. http://edukasi.kompasiana.com.

Prastowo, Andi. (2016). Metode penelitian dan pengembangan di sekolah. Yogyakarta: Media Akademi Yogyakarta

Sagala, S. (2008). Konsep dan Makna Pembelajaran. Bandung: CV Alfabeta

Sugiyono. (2015). Metode Penelitian dan Pengembangan (Research and Development/ $R \& D$ ). Bandung : CV. Alfabeta. 